\title{
An Assessment of the Comfort Level of Cancer Patients with Receiving Chemotheraphy
}

\section{Kemoterapi Alan Kanser Hastalarının Konfor Düzeylerinin Değerlendirilmesi}

\section{(D) Aysun CAN, iD Sevilay HINTISTAN}

Karadeniz Technical University Faculty of Health Sciences, Department of Nursing, Trabzon, Turkey

\begin{abstract}
Objective: The study aimed on determining the comfort level of cancer patients with receiving chemotheraphy and to evaluate the factors that have an impact on this.

Methods: The study was conducted with 213 patients who received cancer chemotherapy. It was designed as a cross-sectional and descriptive model. A Patient Information Form and General Comfort Questionnaire was administered to patients in person. For the data assessment, frequency, percentages, the t test, one-way variance analysis, the Mann-Whitney U test, Kruskal -Wallis H test, and the Dunnet T3 Post Hoc test were employed.
\end{abstract}

Results: The average General Comfort Questionnaire score for patients was $2.93 \pm 0.35$. Patients psychospiritual comfort was at the highest degree $(39.72 \pm 5.87)$, while environmental comfort was at the lowest degree $(35.58 \pm 6.45)$. Patients comfort level was significantly affected by sex, age and profession $(\mathrm{p}<0.05)$, whereas it was not affected significantly by marital status, educational status, person(s) with whom they lived cancer type, duration of cancer ( $\mathrm{p}>0.05)$.

Conclusion: Patients in the study had moderate comfort levels. There is increased recognition that cancer patients comfort needs should be explored, and practices that will enhance their comfort level should be promoted.

Keywords: Cancer survivors, chemotherapy, oncology nursing, patient comfort

\section{ÖZ}

Amaç: $\mathrm{Bu}$ çalışma kemoterapi alan kanser hastalarının konfor düzeyini ve bunu etkileyen faktörleri değerlendirmek amacı ile yapıldı.

Yöntemler: Çalışma kanser kemoterapisi alan 213 hasta ile gerçekleştirildi. Çalışma, kesitsel ve tanımlayıcı tipte yapıldı. Hastalara yüz yüze görüşme tekniği ile Hasta Bilgi Formu ve Genel Konfor Ölçeği uygulandı. Verilerin değerlendirilmesinde frekans, yüzde, t testi, tek yönlü varyans analizi, Mann-Whitney $U$ testi, Kruskal-Wallis H testi, Dunnet T3 Post Hoc testi analizi testleri kullanıldı.

Bulgular: Hastaların Genel Konfor Ölçeği puan ortalaması $2,93 \pm 0,35$ 'tir. Hastaların psikospritüel konfor boyutu en yüksek düzeyde $(39,72 \pm 5,87)$ iken çevresel konfor boyutu en düşük düzeydedir $(35,58 \pm 6,45)$. Hastaların konfor düzeyini cinsiyet, yaş ve meslek anlamlı olarak etkilerken $(\mathrm{p}<0,05)$; medeni durum, eğitim düzeyi, evde birlikte yaşanan kişiler, kanser türü ve kanser süresi anlamlı olarak etkilememiştir ( $p>0,05)$.

Sonuç: Hastaların konfor düzeyi orta düzeydedir. Kanser hastalarının konfor gereksinimleri belirlenerek konfor düzeylerini artırabilecek uygulamaların yapılması önerilir.

Anahtar Sözcükler: Kanser hastaları, kemoterapi, kanser hemşireliği, hasta konforu
Address for Correspondence: Sevilay HINTISTAN, Karadeniz Technical University Faculty of Health Sciences, Department of Nursing, Trabzon, Turkey

E-mail: sevilayhindistan@gmail.com ORCID ID: orcid.org/0000-0002-5937-5723
Received: 20.02 .2020

Accepted: 24.04 .2020

Cite this article as: Can A, Hintistan S. An Assessment of The Comfort Level of Cancer Patients With Receiving Chemotheraphy. Bezmialem Science 2021;9(3):310-16. 


\section{Introduction}

Cancer, characterized with impairment in programmed cell death and excessive cell proliferation, is a chronic disease with challenges in diagnosis, treatment, and care processes $(1,2)$. The World Health Organization has reported that there are 18.1 million new cancer cases throughout the world each year, and cancer-related mortality was 9.6 million in 2018 (1). In Turkey, $20.7 \%$ of the deaths in 2014 were caused by cancer (2).

With early diagnosis and advancements in treatment and care, patients' lifespan with cancer has been extended. These positive developments have now brought a focus on the possibilities for patients' longer and improved quality of life $(3,4)$. A diagnosis of cancer often evokes many emotional, psychological, and behavioral responses. These can include guilt, abandonment, anxiety, pain, grief, and thoughts of dying, which can trigger many symptoms that negatively affect a person's comfort and well-being $(5,6)$. One of the major weapons used in the treatment of cancer is the use of chemotherapy. Although it can produce many positive outcomes, this treatment also causes a great number of negative side effects. Many cancer patients experience nausea, emesis, pain, diarrhea, alopecia, fatigue, and sleeplessness. Other side effects include psychological problems such as feelings of despair, depression, anger, anxiety, fear, hopelessness, vulnerability, and loss of control $(3,5,7)$. The social problems that many patients confront are those of isolation, role changes, loss of work, difficult interpersonal relations, and decreased interest in their social environment (8).

The term "comfort," defined as "lack of pain, distress, worry and uneasiness," has been analyzed by Katharina Kolcaba. Kolcaba defines comfort as "the immediate state of experience of solving problems and thus having comfort by being strengthened through answering the human needs for relief and ease and transcendence in physical, psychospiritual, environmental, and sociocultural contexts" (9-11). Cancer patients with a large number of physical, psychosocial, socio-cultural, and environmental problems often receive palliative care services $(12,13)$. Palliative care is said to focus on eight elements: evaluations and consultations, tests, care practices, pharmacotherapy, diet, activity-environment safety, patient and family education, and discharge planning, which intend to increase patient comfort when managing their disease (14). With cancer treatment, palliative care is often part of comfort care, specifically providing psychosocial and spiritual support and symptom control $(13,14)$.

Other goals for comfort care are to offer cancer patients encouragement, hope, feelings of control over their life, and to enhance their decision-making skills $(9,15)$. Comfort care, which is an inseparable part and basis of nursing services, is a therapeutic nursing practice. Although each patient has different comfort needs, all comfort dimensions may affect each other negatively or positively. Therefore, comfort care, emphasizing individual needs and a holistic approach, is both a desired outcome and an indication of productivity $(10,16)$. By assessing cancer patients' comfort levels, physical needs psychospiritual needs, sociocultural needs and environmental needs, health care personnel will be able to determine ways in which to maximize their patients' comfort as they go through a rigorous and difficult life crisis of ill health $(6,12)$. In one study, it was found that the patient's comfort increased as a result of the attempt to cope with the symptoms of chemotherapy (17). In this way, considering all aspects of the individual's needs can help in the planning, decision making, and implementation of the best nursing interventions possible. A main goal would be to keep the patient's maximum comfort level in focus $(11,18)$.

In Turkey, few studies have been conducted which assess the comfort levels of cancer patients $(6,17)$. For this reason, we believe that this research, which was the first study on comfort done with cancer patients living in the Eastern Black Sea region of Turkey, will make a significant contribution to the existing literature. The study focused on determining the comfort level of cancer patients during their personal and stressful experiences of diagnosis and treatment and to help inform future nursing interventions on how to best comfort oncology patients to improve their quality of life during chemotherapy treatments. The aim of the study was to determine the comfort level of cancer patients and to evaluate the factors that have an impact on this.

\section{Methods}

\section{Study Design}

This cross-sectional and descriptive study was performed to determine comfort levels of patients in the ambulatory chemotherapy unit of one Hospital of University.

\section{The Population and Sample}

The study population was drawn from patients who received cancer chemotherapy during that time, $n=689$ patients in the hospital's medical records between 1 August - 31 December, 2015. The research sample was then calculated to $n=247$ participants, with a $95 \%$ confidence interval and a 5\% margin of error nonreference prevalence of comfort of $50 \%$ being adopted using Open Epi Programs (19). The 247 participants were taken by simple random sampling technique. These patients were recruited mechanically a list of patients from the hospital's medical records who received chemotherapy between 1 August-31 December 2015, and accessing this list was approved by the ethics committee. In the end, the study was conducted with 213 patients after 34 patients dropped out for various reasons like giving up the treatment, moving from the city to another place, interrupting the forms. To be eligible patients needed to know about their cancer diagnosis, regardless of type of cancer and time since diagnosis. Also, they needed to be: 1) receiving chemotherapy; 2) not receiving palliative or hospice care; 3) be over $\geq 18$ years old; 4) have no psychiatric disorders which needed treatment; 5) have no other chronic disease needing continuous treatment; 6) have person/place/time orientation; 7) be able to verbally communicate; and 8) agree to participate in the study. Patients would be excluded if they had a cancer diagnosis before the age of 18 . 


\section{Data Collection Forms}

\section{Patient Information Form}

A researcher designed the Patient Information Form by surveying the relevant studies on patients receiving cancer chemotherapy $(12,15,17)$. The form included seven questions concerning patients (i.e., sex, age, educational status, profession, marital status, cancer type, duration of cancer).

\section{General Comfort Questionnaire (GCQ)}

The GCQ was developed by Kolcaba in 1992 (18). The Turkish adaptation of the GCQ was done by Kuguoglu and Karabacak in 2008 (20), and its Cronbach alpha was found to be 0.85 . In the current study, the Cronbach alpha of the GCQ was found as 0.87 . It was created according to 12 -cell grid called the taxonomic structure involving four dimensions (physical, psychospiritual, environmental, sociocultural) and three levels (relief, ease, transcendence) of theoretical components of comfort which were used to determine patients' needs, evaluate the nursing implementations for increasing comfort levels, and to achieve the expected results about increasing comfort. All items were scored on a Likert scale ranging from 1 (strongly disagree) to 4 (strongly agree). This scale consists 24 positive and 24 negative items (Table 1). The lowest possible GCQ total score was 48 points, average score 1 , and the highest total score was 192 points, average score 4 . The average score is determined by the total score, dividing the number of items. It is suggested that GCQ can be evaluated and used on both total score and average score in both research and practice $(9,10,20)$.

According to studies regarding comfort levels conducted by Kolcaba, the concept of "comfort" has a holistic structure, and therefore should be assessed as a whole. Although nurses know intuitively what comfort is and what nursing interventions are necessary to enhance it, nurses and researchers currently utilize measures of discomfort that designate a neutral sense of comfort as being the absence of a specific discomfort (12). Integration of comfort to nursing care and comfort measurements of patients determines unmet comfort needs allows bundling of interventions in a single patient interaction and aids in creating measures of holistic comfort for documentation (18). Comfort remains a substantive need throughout life, and as such, should be considered an indispensable constituent of holistic nursing care.

\section{Measures}

The data were gathered using the Patient Information Form and the General Comfort Questionnaire (GCQ) by one researcher. Patients who agreed to participate in the study and met the inclusion criteria were asked to sign an informed consent form. Patient Information Form and GCQ were administered faceto-face by the researcher at a suitable time while patients were receiving chemotherapy at the Ambulatory Chemotherapy Unit. The patients were given the option of completing the Patient Information Form and GCQ with or without the researcher's assistance. Data collection took nearly 30 minutes, and the patients were given the chance to ask any question related to the study.

\section{Data Analysis}

All analyses were performed using the Statistical Package for the Social Sciences for Windows IBM SPSS Statistics 22.0. Skewness, Kurtosis, Kolmogorov-Smirnow, and Shapiro-Wilk values were used to determine whether the sample followed a normal distribution. For the data analyses, frequency, percentages, the t-test, one-way variance analysis, the Mann-Whitney U test, the Kruskal-Wallis $\mathrm{H}$ test, and the Dunnet T3 Post Hoc test were used. Results were considered significant at $\mathrm{p}<0.05$, and the confidence interval was set at $95 \%$.

\section{Ethical Considerations}

The protocol of the study was approved by the ethical review boards at the authors' institution and the hospital. In order to conduct the study, written permissions were obtained from

Table 1. 12-cell called the taxonomic structure of GCQ

\begin{tabular}{|c|c|c|c|}
\hline \multirow{2}{*}{ Subscales of comfort } & \multicolumn{3}{|c|}{ Comfort levels of subscales } \\
\hline & Relief (16 items) & Ease (17 items) & Transcendence (15 items) \\
\hline $\begin{array}{l}\text { Physical (12 items) } \\
\text { †Total score } 12-48 \\
{ }^{\ddagger} \text { Average score } 1-4\end{array}$ & $14 \uparrow, 19 \rrbracket, 48 \uparrow, 25 \uparrow$ & $1 \S, 36^{\S}, 20 \uparrow, 28 \uparrow$ & $15^{\S}, 29^{\S}, 5^{\uparrow}, 6 \rrbracket$ \\
\hline $\begin{array}{l}\text { Psychospiritual (13 items) } \\
\text { †Total score } 13-52 \\
{ }^{\ddagger} \text { Average score } 1-4\end{array}$ & $44^{\S}, 46^{\S}, 22^{\uparrow}, 40^{\uparrow}$ & $2^{\S}, 7^{\S}, 31^{\S}, 38^{\S}, 24^{\uparrow}$ & $9^{\S}, 17^{\S}, 41^{\Uparrow}, 45^{\natural}$ \\
\hline $\begin{array}{l}\text { Environmental ( } 13 \text { items) } \\
\text { †Total score } 13-52 \\
{ }^{\ddagger} \text { Average score } 1-4\end{array}$ & $3^{\S}, 27^{\S}, 12^{\uparrow}, 34^{\Uparrow}$ & $11^{\S}, 47^{\S}, 32^{\uparrow}, 42^{\natural}$ & $30^{\S}, 33^{\S}, 18^{\natural}, 21^{\uparrow}, 35^{\natural}$ \\
\hline $\begin{array}{l}\text { Sociocultural (10 items) } \\
\text { †Total score } 10-40 \\
{ }^{\ddagger} \text { Average score } 1 \text {-4 }\end{array}$ & $37^{\S}, 8^{\uparrow}, 13^{\uparrow}, 26^{\Uparrow}$ & $4^{\S}, 23^{\S}, 43^{\S}, 39^{\Uparrow}$ & $10^{\S}, 16^{\S}$ \\
\hline
\end{tabular}


the hospital. The study was granted ethical clearance by the Institutional Review Board of the University (IRB no: 201524237859-388) and was undertaken in compliance with the Helsinki Declaration. Permission was obtained to use the questionnaire from Kuguoglu and Karabacak (20) adapting in Turkish of the GCQ. In addition, verbal and written consent was obtained from each patient prior to the study.

\section{Results}

A total of 213 patients were taking cancer chemotherapy were included in the study. When the descriptive characteristics of the patients were examined, it was determined that their $59.2 \%$ female, $43.7 \%$ 50-64 years, 55.8\% literate/primary school, $46.5 \%$ housewives, and $85.9 \%$ married. Besides, when the disease information of the patients was looked at, it seemed that their type of cancer $36.6 \%$ breast cancer, $31.5 \%$ gastrointestinal system cancer, and the durations of cancer $52.1 \%$ one year and less.

Patients' average GCQ score and total GCQ score are in Table 2. Patients' average GCQ score was found to be $2.93 \pm 0.35$, whereas their total GCQ score was $140.63 \pm 16.86$.

Table 3 presents the cross-sectional and descriptive statistics patients' average GCQ, and subscale scores according to taxonomic structure. Patients' total scores for the GCQ subscales were physical subscale $34.80 \pm 5.33$, psychospiritual subscale $39.72 \pm 5.87$, environmental subscale $35.58 \pm 6.45$, sociocultural subscale $30.53 \pm 3.56$; relief $47.39 \pm 5.92$, ease $49.57 \pm 6.85$ transcendence $43.67 \pm 6.28$. Patients' total scores for the GCQ subscales were the highest is the psychospiritual subscale, and the lowest is the environmental subscale.

Table 4 shows the GCQ mean scores according to some characteristics. It was found that there were statistically significant differences between patients' GCQ and sex ( $\mathrm{p}=0.036)$, age $(\mathrm{p}=0.028)$, and profession $(\mathrm{p}=0.002)$. However, no statistically significant differences were found between the GCQ and marital status, educational status, type of cancer, and duration of cancer $(\mathrm{p}>0.05)$.

\section{Discussion}

Our results showed that the patients' average comfort level was above 2 out of 4 levels of comfort. This means the patients feel fairly comfortable. Our results were in agreement with a similar study, which was conducted with breast cancer patients receiving chemotherapy, found the comfort level higher than 2 (15). Other studies which used derivates Kolcaba's GCQ with similar scales and questions, reported similar results with this study $(6,12,17)$.

Amoung the subtypes of comfort, the psychospiritual comfort dimension is found the highest. Besides, the data in the current study showed that the level of patients' comfort was transcendence level which was the top level of comfort. It was considered that they were able to cope with their fears, and overcome bothersome symptoms more effectively during the cancer treatment process. A similar result by Bilgic and Acaroglu (17) reported that cancer patients' psychospiritual comfort dimension were found to be at

Table 2. Patients' total score and average score of GCQ ( $n=213$ )

\begin{tabular}{|l|l|l|}
\hline GCQ & Mean \pm SD & Min - max \\
\hline †Total score (48-192) & $140.63 \pm 16.86$ & $92-177$ \\
\hline${ }^{\dagger}$ Average score (1-4) & $2.93 \pm 0.35$ & $2.29-3.42$ \\
\hline
\end{tabular}

GCQ: General Comfort Questionnaire, SD: Standard deviation, Both of " " and "ł" have the same meaning in GCQ, Min: Minimum, Max: Maximum

Table 3. Patients' average GCQ and subscale scores according to taxonomic structure $(n=213)$ Comfort levels

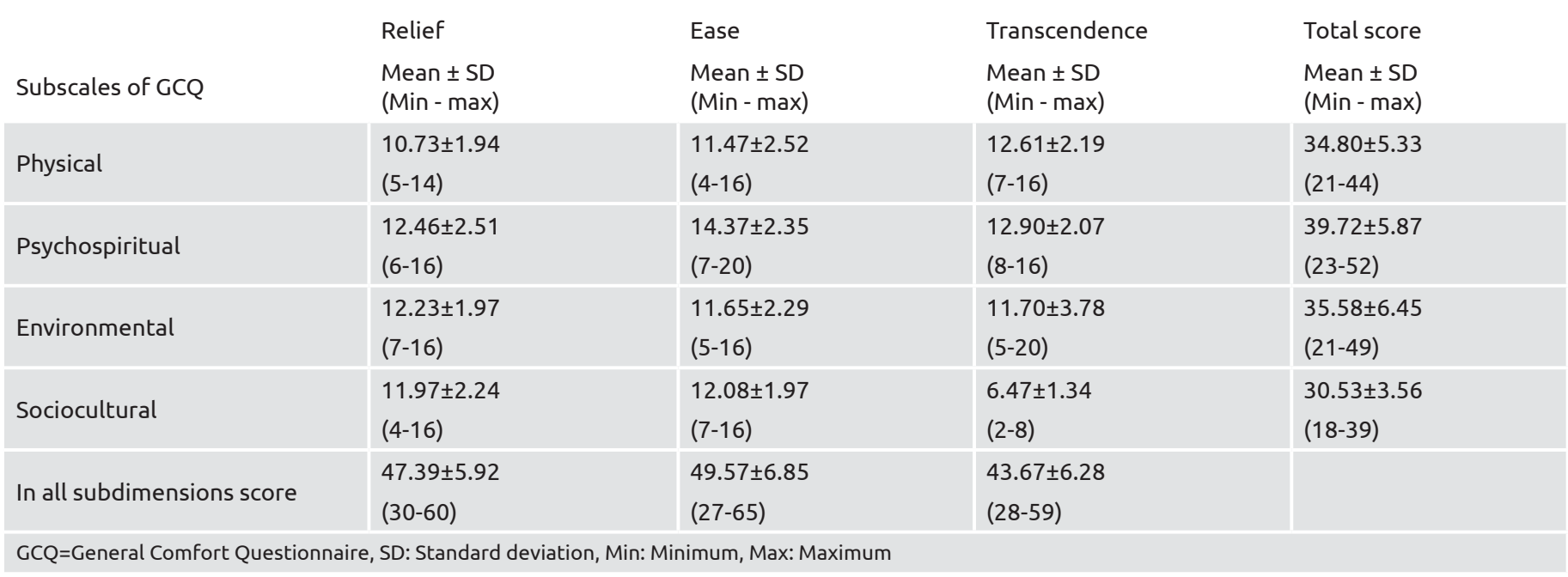


Table 4. Patients' average GCQ scores according to demographic characteristics ( $n=213$ )

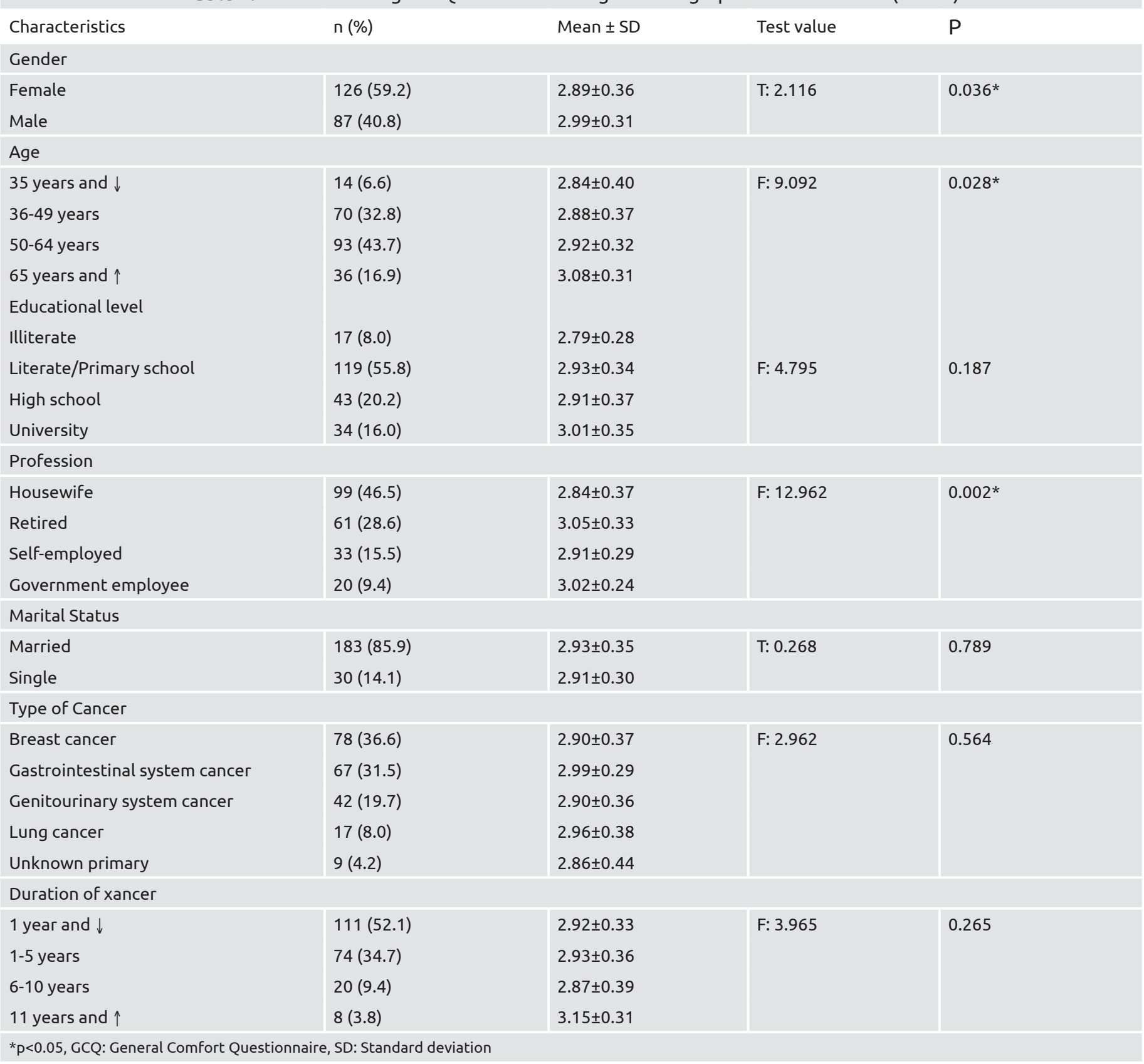

the highest. A previous research study shows that cancer patients emphasize that they use spiritual coping methods such as faith, prayer, and that these methods enhance their coping skills (21).

The sociocultural comfort dimension was found as comfortable which was almost the same as psychospiritual comfort dimension of patients. This study obtained a level of transcendence in the cancer patients' sociocultural comfort dimension. It is also found similar results in study with patients' sociocultural comfort score which was the best comfortable and feeling the best amongst other sub-dimensions (12). Sociocultural comfort of patients is the highest compared to other subdimensions and transcendence level they probably feel more loved, remembered, belonged (22). Korean patients with cancer was found to have eight attributes: "acceptance, self-control, goals of life, change in belief, and positive attitude, supportive relationships, therapeutic environment, and reliance on faith." (23).

In the current study, patients' physical dimension was found to be moderate. In line with the current study, a study done with cancer patients, identified the physical comfort level as moderate (17). Because patients' GCQ physical comfort levels were above 2 out of 4 levels of comfort and transcendence, we concluded that patients did not have serious difficulties in coping with physical symptoms; they may not feel uncomfortable and, able to handle cancer' these symptoms. 
The current study showed that the participants' environmental comfort dimension was at the most uncomfortable area. However, the patients are best comfortable at the relief level in terms of environmental comfort. It was thought that filling the scale in hospital conditions which may adversely affect the patient's comfort could affect the comfort of patients. Similarly, another patient study found that the environmental comfort subscale was the worst of all other comfort subscales (17). The study of Chen and Cheng (24) detected a decrease in the environmental comfort subscale because hospital conditions are different from conditions at home. The patients who were included in Kim and Kwon (12) study were determined that the highest level of environmental comfort respectively the patients who were followed at home, day care chemotheraphy unit, outpatient clinic and inpatient unit.

The current study found that male patients' were considerably higher comfortable than that of female patients. It is guessed that women's greater responsibilities in their lives outside work may explain their feeling less comfortable. Similarly, in a study when asked to indicate the actual side effects experienced during chemotherapy, women being significantly more affected than men. In the same study, women generally reporting more uncomfortable than men (25).

This current study also found that as age increased, so did aged $\geq 65$ years was considerably higher comfortable than for other age groups. Interestingly, although functioning and symptoms differed significantly with age, they were not related to comfort (12). Indeed, the older a person is when they are first diagnosed with cancer, the more they seem able to adapt to their new health situation, and developed more effective coping skills, and have feeling more comfortable (26). However, different studies done with cancer patients did not determine a significant correlation between age and comfort level $(15,21)$.

One study has revealed that cancer patients' comfort level may be elevated because they have been able to maintain their professional life and social responsibilities (3). In the current study, patients who were government employees, and retired employees were significantly higher comfortable than the housewives. This may possibly suggest that patients who were government employees with a regular income, job satisfaction, and social responsibilities demonstrated greater comfort, and were thus able to cope with diseases, and health crises more effectively.

The GCQ is an effective measurement tool that determines the comfort level of cancer patients. Nurses should administer the GCQ at any time points in the patients' chemotherapy. The GCQ needs more research to increase its usability in practice. However, the results of this study may increase awareness among individuals in the occupational healthcare field about the associations between GCQ, and health, and work-related variables. In particular, emphasis should be put on development of assessment, and monitoring tools for use in everyday clinical practice.

\section{Study Limitations}

The limitation of the study was that only patients hospitalized in the ambulatory chemotherapy unit of Hospital of University were included in the study. The results of this study are therefore directed at patients receiving treatment in this unit. The results of this study cannot be generalized to all patients.

\section{Conclusion}

The results of the current study indicated that cancer patients' comfort level was above the average. The psychospiritual comfort aspect was at the best degree, and sex, age, and profession affected the comfort level. In order to provide the highest level of nursing care for cancer patients, their comfort needs must first be determined before a care plan can be properly implemented. Nurses are responsible for planning, and executing the interventions which can increase patients' comfort. Accordingly, nurses should cooperate with the family to determine the comfort levels of patients during treatment, and to control the negative factors that may arise. Factors that decreasing and increasing comfort in the treatment process of chemotherapy patients should be identified. Patients who will be receiving outpatient chemotherapy should undergo an examination with comfort scale before, during, and after their therapy.

\section{Ethics}

Ethics Committee Approval: In order to conduct the study, written permissions were obtained from the hospital. The study was granted ethical clearance by the Institutional Review Board of the University (IRB no: 2015-24237859-388).

Informed Consent: Patient Information Form and GCQ were administered face-to-face by the researcher at a suitable time while patients were receiving chemotherapy at the Ambulatory Chemotherapy Unit.

Peer-review: Externally peer reviewed.

\section{Authorship Contributions}

Concept: A.C., S.H., Design: A.C., S.H., Data Collection or Processing: A.C., S.H., Analysis or Interpretation: A.C., S.H., Literature Search: A.C., S.H., Writing: A.C., S.H.

Conflict of Interest: No conflict of interest was declared by the authors.

Financial Disclosure: The authors declared that this study received no financial support.

\section{References}

1. World Health Organization (WHO). Cancer 2018. [Internet]. [cited 2020 Feb 18]. Available from: https://www.who.int/cancer/ PRGlobocanFinal.pdf.

2. Turkey Statistical Institute. Statistics with Turkey 2013-2014 [Internet]. [cited 2018 Sep 2]. Available from: http://www.tuik.gov. tr. 
3. Keim-Malpass J, Levine B, Danhauer SC, Avis NE. Work-related perceptions and quality of life among breast cancer survivors. PsychoOncology 2016;25:873-6.

4. Radice LM, Eagan J, Michie KY, Pearson M, PetitJH. Initial experience with an innovative pilot program evaluating a multidisciplinary approach to supportive care planning in a survivorship clinic setting. [Internet]. International Journal of Radiation Oncology 2015;93:489.

5. Bag B. Psycho-oncology, psychosocial problems and measurement methods. Current Approaches in Psychiatry 2012;4:449-69.

6. Tuncer G, Yucel SC. Comfort and anxiety levels of women with early stage breast cancer who receive radiotherapy. Asian Pacific Journal of Cancer Prevention 2014;15:2109-14.

7. Cakmak S, Nural N. Incidence of and risk factors for development of oral mucositis in outpatients undergoing cancer chemotherapy. International Journal of Nursing Practice 2019; 25:19.

8. Borstelmann NA, Rosenberg SM, Ruddy KJ, Tamimi RM, Gelber S, Schapira L, et al. Partner support and anxiety in young women with breast cancer. Psycho-Oncology 2015;24:1679-85.

9. Karabacak U, Acaroglu R. The comfort theory. Maltepe University Science and Art Magazine 2011;4:197-202.

10. Kolcaba K. Katherine Kolcaba's comfort theory. In: Smith MC, Parker ME. (Eds), Nursing Theories and Nursing Practice. United States of America: Davis Company. 2015;(4th ed.):S381-91.

11. Erdemir F, Cirlak A. Concept of comfort and its use in nursing. Dokuz Eylül University School of Nursing Electronic Journal 2013;6:224-30.

12. Kim KS, Kwon SH. Comfort and quality of life of cancer patients. Asian Nursing Research 2007;1:125-35.

13. Nuraini T, Gayatri D, Rachmawati I. Comfort assessment of cancer patient in palliative care: A nursing perspective. International Journal of Caring Sciences 2017;10:209-15.

14. Ozcelik H, Fadiloglu C, Karabulut B, Uyar M, Elbi H, Eyigor S, et al. Case management based multidisciplinary care protocol in the palliative care of cancer patients. Journal of Pain 2014;26:47-56.
15. Yilmaz SG, Arslan S. Effects of progressive relaxation exercises on anxiety and comfort of Turkish breast cancer patients receiving chemotherapy. Asian Pacific Journal of Cancer Prevention 2015;16:217-20.

16. Kolcaba K, Tilton C, Drouin C. Comfort theory: A unifying framework to enhance the practice environment. Journal of Nursing Administration 2006;36:538-44.

17. Bilgic S, Acaroglu R. Effects of listening to music on the comfort of chemotherapy patients. Western Journal of Nursing Research 2017;39:745-62.

18. Kolcaba KY. Holistic comfort: operationalizing the construct as a nurse-sensitive outcome. Advances in Nursing Science 1992;15:1-10.

19. Open Source Epidemiologic Statistics for Public Health (OpenEpi). (2019). [Internet]. [cited 2019 April 10]. Available from:

20. Kuguoglu S, Karabacak U. Adaptation and validation of the Turkish version of the General Comfort Scale. Florence Nightingale Nursing Journal 2008;16:16-23.

21. Kavradim ST, Ozer ZC. Hope for cancer patients. Current Approaches to Psychiatry 2014;6:154-64.

22. Apostolo J. Suffering and comfort in patients undergoing chemotherapy. [Internet]. [cited 2018 Oct 10].

23. Kim KO, Kim JA. Concept Analysis of Fighting Spirit in Korean Patients with Cancer. Korean Journal of Adult Nursing 2019;31:5060.

24. Chen Y, Cheng S. Comfort care for a hepatocellular carcinoma patient in hospice ward. BMJ Supportive \& Palliative Care 2013;3:278.

25. Lorusso D, Bria E, Costantini A, Maio DM, Rosti G, Mancuso A. Patients' perception of chemotherapy side effects: Expectations, doctor-patient communication and impact on quality of life-An Italian survey. European Journal of Cancer Care 2017;26:1-9.

26. Alan O, Gursel O, Unsal M, Altin S, Kilciksiz S. Oncologic approach in geriatric patients. Okmeydani Medical Journal 2013;29:94-8. 